\title{
Research Paper \\ Comparing the Effectiveness of Acceptance and Commitment Therapy and Compassion Focused Therapy on Worry Severity and Loneliness Among the Pa- tients With Multiple Sclerosis
}

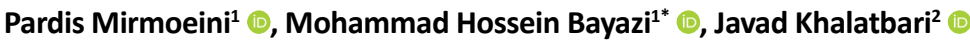

1. Department of Psychology, Torbat -e- Jaam Branch, Islamic Azad University, Torbat-e- Jam, Iran. 2. Department of Psychology, Tonekabon Branch, Islamic Azad University, Tonekabon, Iran.

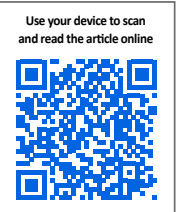

chtation Mirmoeini P, Bayazi MH, Khalatbari J. Comparing the Effectiveness of Acceptance and Commitment Therapy and Compassion Focused Therapy on Worry Severity and Loneliness Among the Patients With Multiple Sclerosis (Persian)]. Quarterly of "The Horizon of Medical Sciences". 2021; 27(4):534-549. https://doi.org/10.32598/hms.27.4.3426.1

doi https://doi.org/10.32598/hms.27.4.3426.1

Key words: Therapy, Compassion, Commitment, Multiple sclerosis, Loneliness, Worry

\section{ABSTRACT}

Received: 07 Jul 2020

Accepted: 20 Jul 2021

Available Online: 01 Oct 2021

Aims Because of the increasing number of patients with multiple sclerosis (MS) and the psychological complications that affect this group, the current study has compared the effectiveness of Acceptance and Commitment Therapy (ACT) and Compassion Focused Therapy (CFT) on these patients.

Methods \& Materials This research is a quasi-experimental study with a pretest-post-test design and a control group. A total of 45 patients with MS were selected from the patients of an MS Clinic in Tehran City, Iran, in 2019. Then, they were randomly divided into two experimental groups of ACT and CFT and one control group. The participants completed the social and emotional loneliness scale for adults and the Penn State worry questionnaire before and after the intervention. The experimental groups participated in eight sessions of ACT and ten sessions of CFT. The control group did not receive any intervention, and in the end, a post-test was taken. The obtained data were examined by analysis of covariance

Findings Findings obtained from univariate analysis of covariance at the statistical level of $P<0.05$ were $F=42.60$ for loneliness and $F=5.90$ for worry, which indicates the more effectiveness of ACT.

Conclusion It is suggested that ACT treatment be given more attention in controlling patients' psychological symptoms.

\section{English Version}

\section{Introduction}

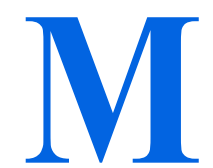

ultiple Sclerosis (MS) is a chronic disease of the central nervous system that affects the brain and spinal cord [1]. MS's age of onset is mostly between 20 and 40 years. According to the World Health Organization, the prevalence of the disease in Iran is 20-60 per 100000 people, and the rate in women is 3 to 4 times that in men [2].
The disease does not affect all people in the same way and has different manifestations [3]. The physical structure of the individual, disorders in the regulation and balance of the immune system, environmental and racial factors, exposure to viruses during life, vaccination, and stress are among the factors that affect the development of MS [4]. Also, many psychological factors, including coping, creation, self-efficacy, and perceived support, contribute more than biological factors to the quality of life of MS patients. Therefore, interventional studies should consider the psychological

\section{*Corresponding Author:}

Mohammad Hossein Bayazi, PhD.

Address: Department of Psychology, Islamic Azad University, Torbat-e-Jam, Iran.

Tel: +98 (515) 2547041

E-mail: bayazi123@gmail.com 
factors associated with the health of these patients and go beyond physical damages and their disabilities [5].

Depending on the level of disability after the first 5 or 10 years of the disease, the future course of the disease can be determined to an acceptable extent 16]. MS is an incurable brain disease that strongly causes worries, decreases self-esteem, and forces the patients to adapt to disease disabilities. According to many sufferers, there is a strong association between anxiety and disease recurrence. During worries, more energy is needed to think and solve daily living problems, and this energy depletion causes fatigue and disruption of patients' daily functioning [7]. Psychological stresses are mentioned as a possible factor for disease recurrence and progression [8]. Loneliness is a risk factor for increased complications and mortality. People with MS are subject to an increased risk of loneliness [9]. The studies on the relationship between loneliness and physical and mental health show that loneliness affects the various aspects of the social life of individuals. The sense of loneliness is predictive of symptoms of depression [10]. MS also causes severe anxiety in patients and forces them to adapt to the disabilities caused by the disease. According to many patients with MS, there is a strong association between anxiety and disease recurrence. Most of the patients report that the symptoms of the disease worsen during times of stress and anxiety [11]. Statistics show the ascending course of the disease in the world, so in our country, it is necessary to take serious action to control and treat the disease. Psychological problems in MS are more common than in healthy populations and other chronic diseases [12]. Empirical research suggests a high rate of depression and loneliness, an increase in anxiety, and problems related to relationships and social roles in MS patients, so it is necessary to find appropriate and effective solutions for the better life of these patients.

Compassion means having a positive attitude towards oneself when things go wrong. Compassion itself is considered an effective trait and a protective factor in cultivating emotional flexibility. Compassion includes kindness to oneself in the face of self-judgment and criticism, human communication in the face of isolation, and mindfulness in the face of over-imitation of others. Compassion leads to a sense of self-care, self-awareness, an unbiased view of one's inadequacies and failures, and the acceptance that one's experiences are also part of ordinary human experiences. Compassion requires the acceptance that suffering, failure, and inadequacy are part of the condition of life and that all human beings, including the individual, deserve kindness and compassion [13]. Kindness to oneself is self-understanding instead of self-judgment and a kind of support for one's shortcomings and inadequacies. Acknowledging that all human beings are flawed, make mistakes, and engage in unhealthy behaviors is characteristic of shared human emotions [14]. In self-compassion focused therapy, clients are helped by creating or enhancing a client's inner compassionate relationship with themselves, rather than blaming, condemning, or self-criticizing. The results of self-compassion focused therapy include the importance of well-being, understanding and empathy, empathy, non-judgment and not blaming others, tolerance or resilience to turmoil, and suffering, through attention, thinking, behavior, imagery, feeling, and compassion [15].

Also, creating a rich and meaningful life while accepting its inevitable suffering is an effective way to build a meaningful life through its most deeply guided values while being fully prepared and committed only through a conscious action [16]. Acceptance and commitment-based therapy has been developed as an alternative to more traditional forms of psychotherapy, such as classical cognitive-behavioral therapy. This treatment emphasizes reducing the intensity and the frequency of emotions and annoying thoughts. Instead of trying to alleviate recent annoying thoughts, Acceptance and Commitment Therapy (ACT) emphasizes increasing behavioral efficiency in the presence of unpleasant thoughts and feelings. In other words, the ACT therapist does not attempt to alter the client's disturbing thoughts or reduce his or her unpleasant emotions [17]. Studies show different treatments to change and reduce the psychological consequences of diseases. Research has proven the effectiveness of psychological therapies on mental health problems caused by chronic diseases. ACT therapy is one of the new and effective therapies in solving psychological problems and disorders, the basic principles of which are as follows: 1) acceptance or desire to experience pain or other disturbing events without trying to control them and 2) action based on value or commitment is accompanied by a desire for meaningful personal goals before the elimination of unwanted experiences. Therefore, ACT is very appropriate by focusing on the current situation and the paths leading to acceptance and personal growth in crises. According to the circumstances in the individual's situation, acceptance is gradually created to achieve a sense of self as a socially, sexually, and occupationally appropriate person [18].

A variety of studies on the effectiveness of ACT on improving quality of life [19] have studied reducing pain intensity in MS patients [20], reducing anxiety and dysfunctional attitudes [21], anxiety and depression in women with MS [22], resilience [23], logical memory, problem-solving skills [24], cognitive conflicts, and negative spontaneous thoughts [25].

Compassion Focused Therapy (CFT) teaches people not to let go of their painful feelings but accept them. There- 
fore, in the first step, they know their experience and feel compassion for it [26]. Compassion acknowledges that not all pain can be resolved or cured, but all suffering can be alleviated with a hug of compassion. In fact, with mindfulness based on cognition, we can face the problems and sufferings of life. With compassion, we can deal effectively with them [27]. Since no research has been done on the effectiveness of CFT and ACT on loneliness and anxiety in patients with MS, in the current study, we seek to answer whether the ACT and CFT are effective on loneliness and the severity of worry in patients with multiple sclerosis. Also, if there is a significant difference between these two intervention methods in the effectiveness on the mentioned variables.

\section{Materials and Methods}

The present quasi-experimental study has a pretest-posttest design with a control group. The study population includes all patients with multiple sclerosis under treatment by MS clinic physicians in Tehran City, Iran. The study sample was selected by purposive sampling from $2500 \mathrm{MS}$ patients during the second 6 months of 2019.

The study questionnaires were presented to 166 patients of the statistical population. Among them, 92 people with the highest scores in loneliness and anxiety were identified. Then, 45 people were randomly selected and assigned into three groups of 15: the first experimental group went under CFT, the second experimental group consisted of 15 patients treated based on ACT, and the third group was the control group. According to Dr Delavar, for experimental and comparative studies, a sample size of 30 people in each group is recommended. However, sometimes experimental research is conducted with 15 people in each group under controlled conditions. After the intervention (CFT and ACT groups), the independent variables were observed, measured, and re-evaluated in the post-test.

\section{Results}

The study sample was 45 patients with MS. Of these, 15 were randomly selected and assigned into the first experimental group (ACT), 15 in the second experimental group (CFT), and 15 in the control group. The age range of the participants was between 20 and 40 years, with an average of 28.84 years. The number of females was 0.33 times that of males.

There was no statistically significant difference between the three groups after analyzing qualitative data through descriptive statistics using the indicators of central tendency, dispersion, and frequency distribution of age and educa- tion variables. The scores of the subjects in the pretest for all three groups were at a significant level for testing the normality of the data in all the variables under study was greater than 0.05 , and the assumption of the normality of the distribution of scores was accepted.

Before the intervention, in the pretest, the scores of loneliness and severity of worry were equal in the three groups, but after the intervention, the mean scores of loneliness and the severity of worry decreased in the two experimental groups compared to the control group while no significant change was observed in the control group. Comparing the effect of these two therapies, according to Tables 1 and 2 , ACT is more effective than CFT.

\section{Ethical Considerations}

In this research, ethical provisions have been observed in two parts: executive and written. In the executive part, the privacy and confidentiality of the collected data were observed so that the collected information was used in line with the purpose of this research. Also, in this study, the dignity, rights, privacy, secrets, and freedom of the subjects were observed. The researchers explained the study objectives to the patients and obtained informed consent from them. The other ethical principles observed in this study were the optionality of the research, the right to withdraw from the study, the harmlessness of CFT and ACT, answering questions, and providing results to the subjects if they wished.

The inclusion criteria were 1) having MS, 2) informed consent to participate in research, 3) age range between 20 and 40 years, 4) literacy level above the cycle, 5) no drug addiction, and 6) no use of any sedative that can affect the variables studied (antidepressants, anti-anxiety, and sedatives).

The exclusion criteria were 1) psychosis and use of psychiatric and psychotropic drugs, 2) absence from more than two sessions in treatment sessions, 3) personality disorders, 4) severe family problems, and 5) withdrawal of the subject.

\section{Self-compassion focused therapy sessions}

Self-compassion focused therapy sessions are designed based on the concepts of Paul Gilbert (2010). According to Table 3, the content validity of this package has been approved in Iran with a survey of three clinical psychologists and familiar with the third wave therapies in the universities of Al-Zahra and Kharazmi of Tehran [28]. 
Table 1. Analysis of covariance comparing compassion focused therapy with acceptance and commitment therapy on loneliness in patients with multiple sclerosis

\begin{tabular}{ccccccc}
\hline Source of changes & Sum of Squares & Degree of Freedom & Mean Squares & F & Significance Level & Eta Coefficient \\
\hline Group & 375.49 & 1 & 375.49 & 5.90 & 0.001 & 0.42 \\
Error & 143.61 & 28 & 63.64 & - & - & - \\
Total & 195.45 & 30 & - & - & - \\
\hline
\end{tabular}

\section{Acceptance and Commitment Therapy}

Acceptance and commitment therapy was performed by the researcher, with a degree in acceptance and commitment training, using a treatment protocol whose content and application validity have been validated by psychologists [29]. The sessions are described in Table 3.

\section{Social and emotional loneliness scale for adults}

This scale was designed and developed by DiTommaso, Brannen, and Best in 2004 based on Weiss>s classification. This scale includes 15 items and three subscales of romantic loneliness (five items), family (five items), and social (five items), and the feeling of emotional loneliness is obtained from the sum of scores of romantic and family subscales. Each item is scored on a 5-point scale from «strongly disagree» with a score of 1 to «strongly agree» with a score of 5. All items except items 14 and 15 are scored in reverse, and obtaining a higher score in each of the dimensions of this scale indicates a greater sense of loneliness. The authors of this scale reported the Cronbach $\alpha$ coefficient of 0.87 to 0.90 , which indicates a suitable internal consistency of the scale. In another study by DiTommaso, Brannenn McNally, Ross, and Burgess, the Cronbach $\alpha$ coefficient was reportedly acceptable from 0.81 for romantic loneliness to 0.91 for family loneliness. The validity of this tool has already been confirmed in several studies.

\section{Penn State Worry Questionnaire}

The Penn State worry questionnaire is a 16 -item selfreport questionnaire that measures severe, extreme, and uncontrollable anxiety. The scale of answering questions is based on the Likert scale. In the research of Dehshiri et al. (2009), the results of factor analysis showed that the twofactor model of this questionnaire (general concern and lack of concern) has a better fit than the one-factor model. The internal consistency and test-retest coefficients (with an interval of 1 month) of the questionnaire were high. Also, a significant correlation between the scores of this questionnaire and the scores of the trait anxiety and depression questionnaire indicates the validity of the questionnaire. The reliability of the questionnaire was calculated using the Cronbach $\alpha$ method. Usually, the range of the Cronbach $\alpha$ reliability coefficient is from 0 , meaning instability to +1 , meaning complete reliability. The closer the value obtained to the positive number one is, the more reliable the questionnaire is [30].

\section{Discussion}

This study aimed to compare the effectiveness of ACT and CFT on loneliness and worry in patients with MS and determine which method is more effective. The results showed that ACT and CFT groups were significantly different from the control group, and these therapies effectively improved loneliness and worry intensity. This finding is consistent with other research results in this field [31-38]. Compared with each other, ACT and CFT showed a significant dif-

Table 2. Analysis of covariance comparing CFT With ACT on anxiety in patients with multiple sclerosis

\begin{tabular}{ccccccc}
\hline Source of Changes & Sum of Squares & Degree of Freedom & Mean Squares & F & Significance Level & Eta Coefficient \\
\hline Group & 520.83 & 1 & 520.83 & 42.60 & 0.001 & 0.68 \\
Error & 241.53 & 28 & 8.62 & - & - & - \\
Total & 9077.00 & 30 & - & - & - & - \\
\hline
\end{tabular}


Table 3. Description of the Intervention Sessions

\begin{tabular}{|c|c|}
\hline Sessions & $\begin{array}{l}\text { Content of acceptance and commit- } \\
\text { ment therapy (ACT) sessions }\end{array}$ \\
\hline $\begin{array}{c}\text { First } \\
\text { Session }\end{array}$ & $\begin{array}{l}\text { Establishing a therapeutic relationship, } \\
\text { acquainting people with the subject of } \\
\text { research, and concluding a therapeutic } \\
\text { contract }\end{array}$ \\
\hline $\begin{array}{l}2^{\text {nd }} \\
\text { Session }\end{array}$ & $\begin{array}{l}\text { Discovering and evaluating treatment } \\
\text { methods and evaluating their effective- } \\
\text { ness, discussing the temporality and } \\
\text { ineffectiveness of therapies using alle- } \\
\text { gory, receiving feedback, and present- } \\
\text { ing homework }\end{array}$ \\
\hline $\begin{array}{c}3^{\text {rd }} \\
\text { Session }\end{array}$ & $\begin{array}{l}\text { Assisting clients in identifying ineffec- } \\
\text { tive control strategies and realizing } \\
\text { their futility, accepting painful personal } \\
\text { events without conflict with them using } \\
\text { allegory, receiving feedback, and giving } \\
\text { homework }\end{array}$ \\
\hline $\begin{array}{c}4^{\text {th }} \\
\text { Session }\end{array}$ & $\begin{array}{l}\text { Explaining about avoiding painful expe- } \\
\text { riences and being aware of their con- } \\
\text { sequences, teaching acceptance steps, } \\
\text { changing language concepts using al- } \\
\text { legory, teaching relaxation, receiving } \\
\text { feedback, and giving homework }\end{array}$ \\
\hline
\end{tabular}

Introducing a three-dimensional behavioral model to express the com$5^{\text {th }}$ mon relationship between behavior/ Session emotions, psychological functions, and observable behavior, and discuss the ef fort to change behavior based on it, re ceive feedback, and provide homework

Explain the concepts of role and context, observe the self as a context and make contact with oneself using alle-

$6^{\text {th }}$

Session gory, be aware of different sensory perceptions, and separate from the senses that are part of the mental content, get feedback and provide homework

Explaining the concept of values, moti$7^{\text {th }} \quad$ vating change and empowering clients Session for a better life, practicing focus, getting feedback, and giving homework

Commitment to practicing training identifying behavioral plans according to values and creating commitment to act on them, summarizing sessions, conducting post-test
Content of compassion focused therapy (CFT) sessions

Establishing a therapeutic relationship, acquainting people with the research topic, answering the questionnaire, and concluding a treatment contract

Establishing initial communication, grouping, reviewing the structure of sessions, familiarity with general principles and treatment focused on self-compassion, evaluating and assessing participants' feelings of loneliness and self-criticism, factors related to its symptoms, and self-compassion-based conceptualization, giving homework at the end of the session, ask them to record their daily criticisms and challenges at home, identification, and awareness of loneliness and self-criticism.

Identifying and introducing the components of self-compassion, examining each component of compassion in group members and identifying its characteristics, to get acquainted with the characteristics of people with self-compassion, reviewing the self-compassion of members At the end of the treatment session, the members were asked to record the components of self-compassion in their daily activities as homework. The desired behavior in this session was to identify and be aware of the components of self-compassion.

Reviewing the assignments of the previous session and cultivating a feeling of warmth and kindness towards oneself, the sense that others also have shortcomings and problems (cultivating a sense of human commonalities), in the face of self-destructive and shameful feelings, self-empathy training, formation, and creation of more and more diverse feelings related to people's issues to increase care and attention to their health

At the end of the treatment session, the members were given homework; they were asked to record the components of self-compassion in their daily activities, identify and be aware of the components of self-compassion.

Practicing the previous session, encouraging members to self-knowledge and examine their personality as a person with self-compassion with non-self-compassion, identifying and applying exercises to cultivate a compassionate mind (self-compassion value, empathy, and compassion for self and others, physiotherapy metaphor training), accepting mistakes and forgiving oneself for mistakes to speed up change.

At the end of the treatment session, the members were given homework; they were asked to record their daily mistakes and identify their associated factors. The intended behavior of the participants in this session was to cultivate compassion.

Reviewing and practicing the previous session, familiarizing and applying the exercises of cultivating a compassionate mind (forgiveness, acceptance without judgment, teaching flu metaphor and tolerance training), acceptance training, acceptance of upcoming changes, and enduring challenging situations due to the changing nature of life and facing various challenges

At the end of the treatment session, the members were given homework to be asked to record forgiveness and acceptance without judgment in their challenging daily activities. The behavior of the members in this session was to improve and develop self-compassion.

Reviewing the previous session, practicing to create compassionate images, teaching the styles and methods of expressing compassion (verbal, practical, persuasive), and continuous compassion and applying these methods in daily life, family, and friends, training to develop valuable and transcendent emotions

At the end of the treatment session, the members were given homework; they had to use compassion in their daily activities. The desired behavior of the participants in this session was a feeling and value of self-compassion.

Reviewing the previous session, teaching writing compassionate letters to oneself and others, how to record and write down real situations based on compassion and performance in that situation.

At the end of the treatment session, the members were given homework; they were asked to write compassionate letters to themselves and those around them. The desired behavior of the participants in this session was to improve the feeling and value of self-compassion.

Reviewing and practicing the skills presented in previous sessions to help members cope with different situations in their lives in different ways, and finally summarizing and presenting solutions to maintain and apply this treatment in daily life

At the end of the treatment session, the members were given homework; they were asked to record their self-compassion for daily challenges. The desired behavior of the participants in this session was to cultivate and grow compassion for themselves.

In this session, the previous 9 sessions were reviewed, and the group members were appreciated. Then they were subjected to the same post-test under the same conditions.
Session 
ference, i.e., treatment based on the ACT was preferable. Acceptance and commitment therapy emphasizes releasing individuals from mental traps and defusion. In the ACT approach, the people are helped to get rid of annoying selfassessments and labeling associated with painful emotions and are used as psychological flexibility. They result from a set of processes such as defusion, commitment to values, and self as the basis for acceptance, committed action, and mindfulness.

Compassion focused therapy seeks to clarify key components of compassion, such as sensitivity with attention, motivation to care, compassion, empathy, distress, and a non-judgmental perspective. In fact, cultivating self-compassion, compassion for others, and acceptance of compassion by others can provide a safe and spiritual psychological home, as a result of which individuals can effectively deal with the harmful events of life. CFT acts as a method of positive emotion regulation, reducing negative emotions and replacing them with positive emotions. It seems that due to this emotional self-regulation, psychological problems are reduced. As a result, a person >s perception of his abilities improves, especially in the emotional field and dealing with stressful situations and conditions.

\section{Study Limitations}

One of the limitations of this study is the inability to control all disturbing variables, such as patients $>$ daily problems during treatment due to the coronavirus pandemic conditions and quarantine of these patients, and consequently, lack of follow-up period, lack of research, and similar studies on the subject. The most important limitations of the research were using only the patients with MS referred to Dr Amir Reza Azimi MS Clinic and the use of self-report tools. These limitations should be considered in using the results and generalizing them. Therefore, it is recommended that such research be conducted using interviews instead of questionnaires.

\section{Study Suggestions}

According to the study results, it is suggested that longterm follow-up be used in future research to examine the effectiveness of CFT with ACT more accurately. Considering that the living environment, work, social and economic conditions of individuals affect the research results, caution should be exercised in generalizing the results to the whole society. It is suggested that in future research, the third experimental group should also be considered, which will study the combined treatment of ACT and CFT on the research samples.

\section{Conclusion}

The current study findings compared the effectiveness of CFT with ACT and supported the effectiveness of both treatments in reducing feelings of loneliness and worry in patients with multiple sclerosis. There is also a significant difference in the effectiveness of CFT with ACT, so that ACT is much more effective on patients feelings of loneliness and worry than CFT. Therefore, it is suggested that special attention be paid to the effectiveness of these two therapies in controlling the psychological symptoms of patients with multiple sclerosis, which was confirmed by various research backgrounds in different fields.

\section{Ethical Considerations}

\section{Compliance with ethical guidelines}

This study with the ethical code of IR.IAU. TJ.REC.1399.012 has been approved by the Islamic Azad University of Torbat-e-Jam.

\section{Funding}

This article is extracted from Ms Pardis MirMoeini's $\mathrm{PhD}$ dissertation in Health Psychology.

\section{Authors' contributions}

The main idea of implementing the protocol and writing the manuscript: P. MirMoeini; Manuscript Editing: M.H. Bayazi; Data analysis: Javad Khalatbari.

\section{Conflicts of interest}

The authors declared no conflict of interest.

\section{Acknowledgements}

We sincerely thank Dr. Amirreza Azimi Saein for his cooperation in all the executive and scientific stages of the current research. 
This Page Intentionally Left Blank 


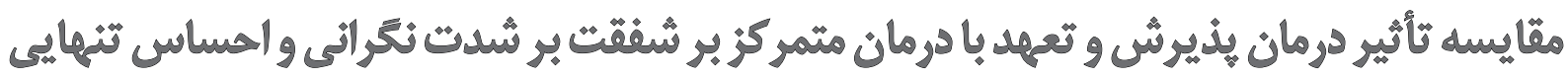

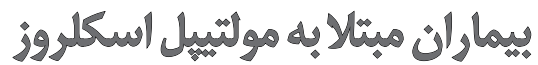

هرديس ميرمعينى' (1)، "محمدحسين بياضى' (1)، جواد خلعتبرى '0.

1. كروه روانشئاسي، واحد تربت جام، دائشاه آزاد اسلامي، تربت جام، ايران.

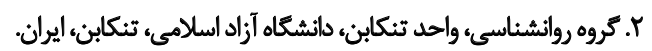

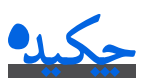

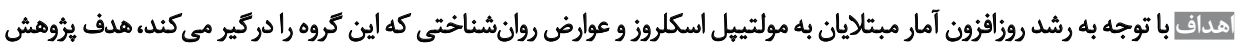

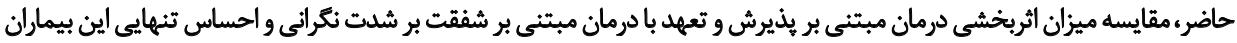

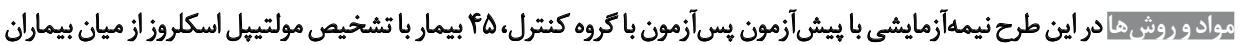

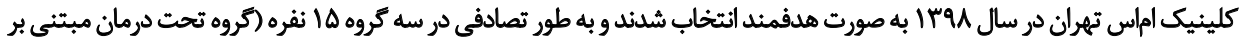

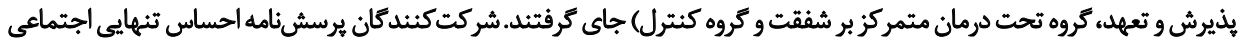

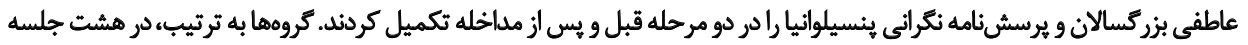

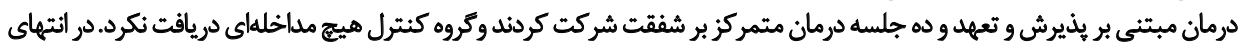

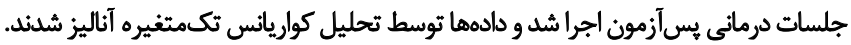

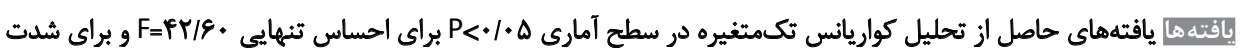

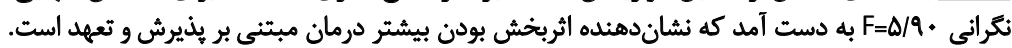

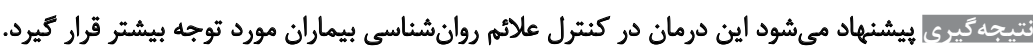

تاريخ دريافت: VIV تير

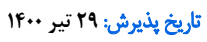

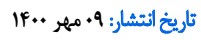

كليدواروها:

درمانه شفقته تعبهد،

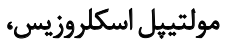
تنهايى، نكرانى

بيش از متغيرهاى بيولوزيك در كيفيت زندكى بيماران مولتيتيل

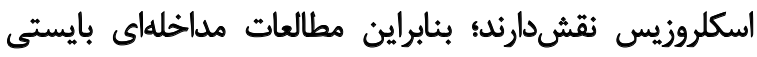

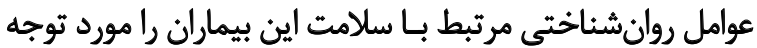

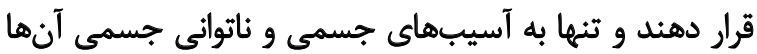

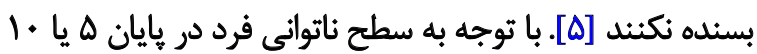

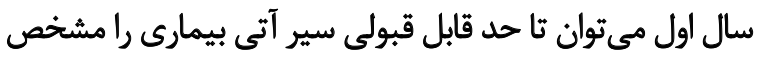

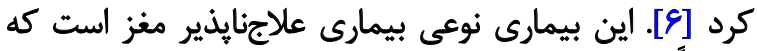

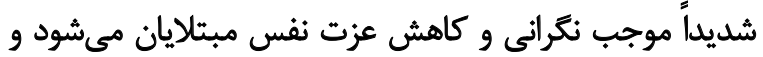

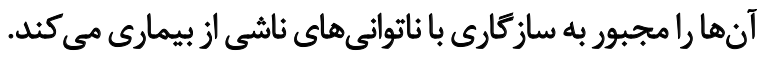

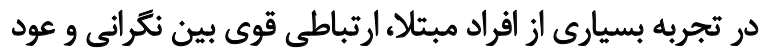

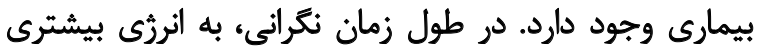

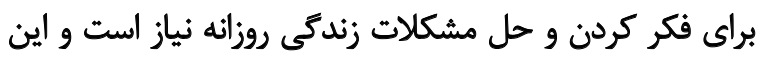

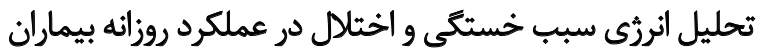
مىشود [V]. فشارهاى روانى به عنوان يك عامل احتمالى براى

مولتييل اسكلروز (اماس) يكى از بيمارىهاى مزمن سيستم

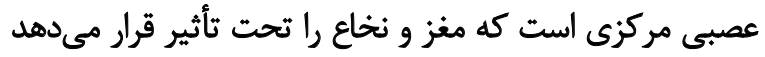

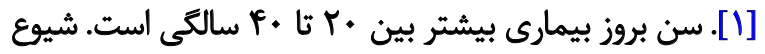

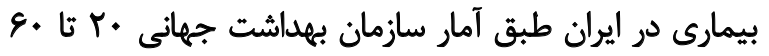

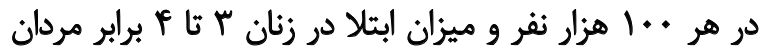

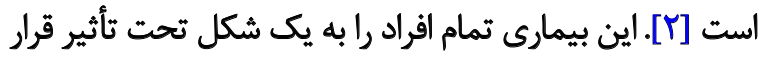

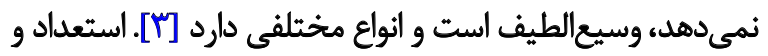

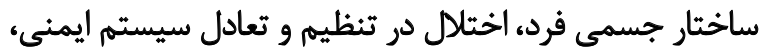

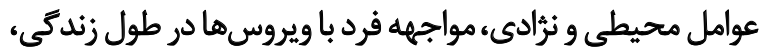

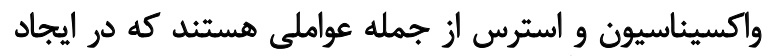

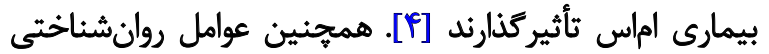
زيادى شامل مقابله، خلق، خودكارآمدى و حمائن عايت ادراكشده ㄷ…...

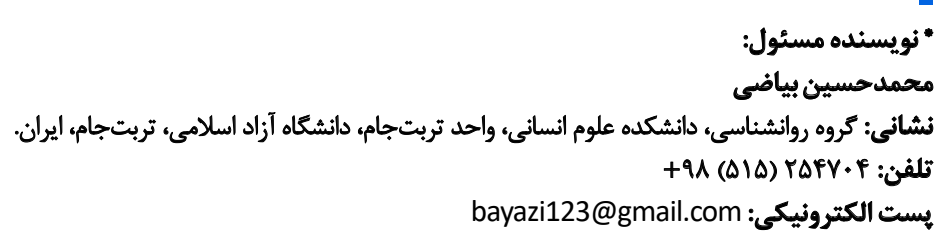


رنج ناتزيراز بيمارى و مشكلات رامى يذيرد، اقدام مؤثرى است كه

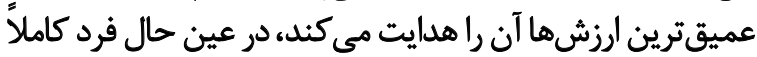

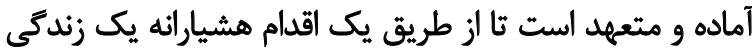

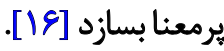

درمان مبتنى بر يذيرش و تعهد (ACT)' به عنوان جايكزينى

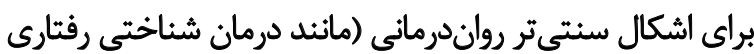

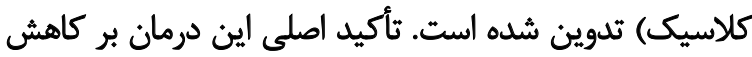

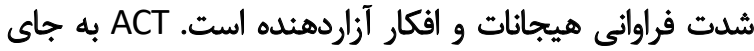
تلاش مستقيم براى كاهش موارد اخير، بر افزايش كارئ آرآمدي

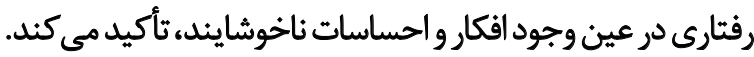

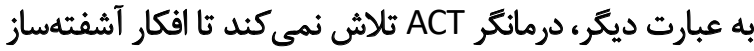

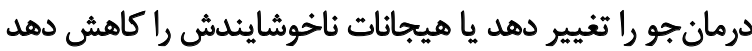

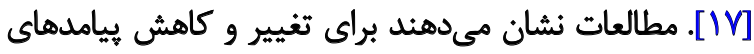

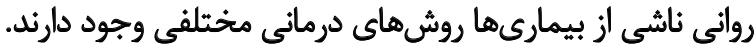

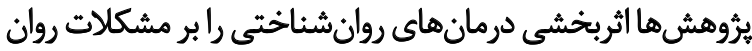

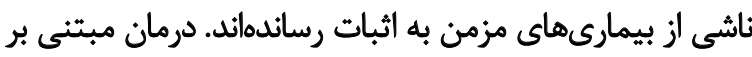

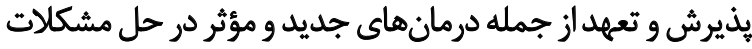

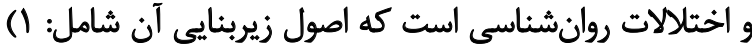

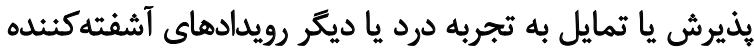

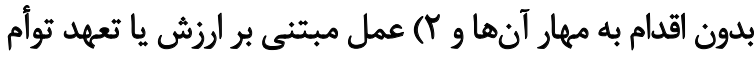

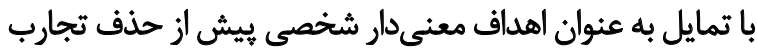

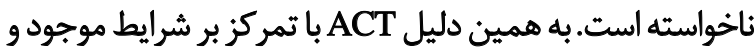

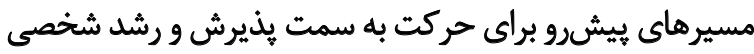

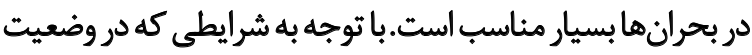

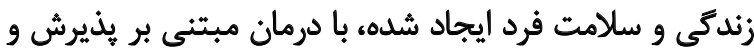

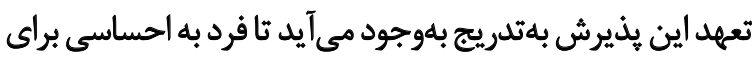

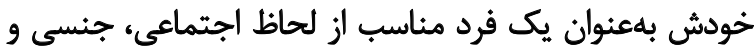

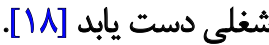

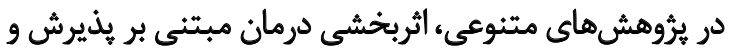

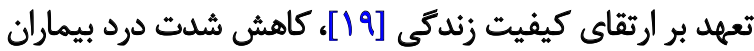

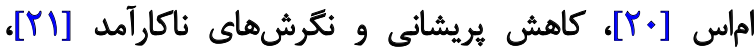

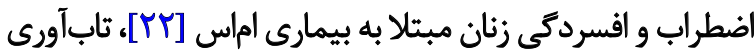

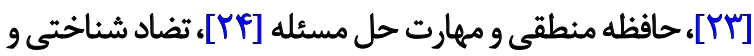

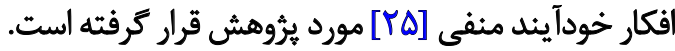

درمان متمركز بر شفقت (CFT) بهاف افراد مى آموزد كهاحساسات

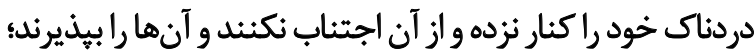

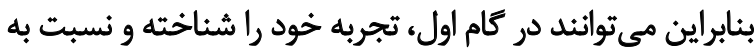

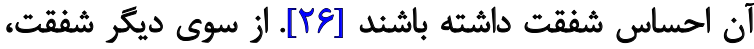

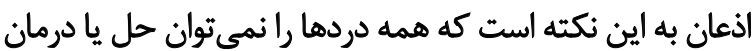

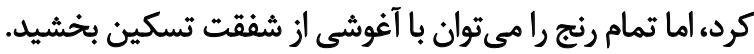

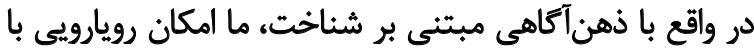

1. Acceptance and Commitment Therapy (ACT)

2. Compassion-Focused Therapy (CFT)

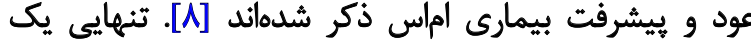

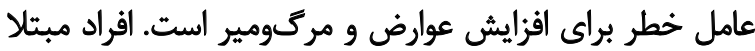

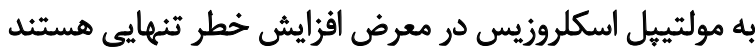

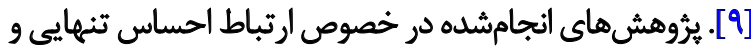

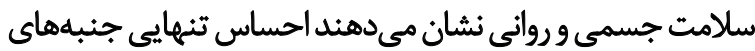

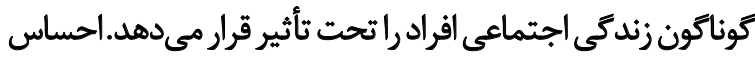

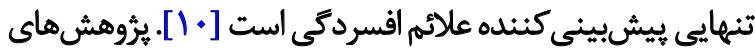

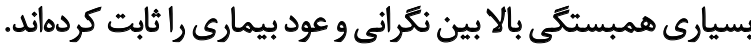

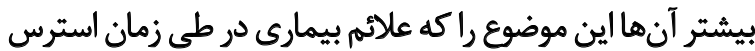
و نكرانى تشديد مى انهود، بيان موضى كنيند [11]. آمارها نشاندهنده سير صعودى اين بيمارى در جهان و در

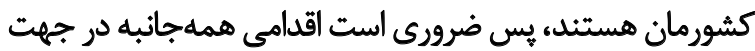

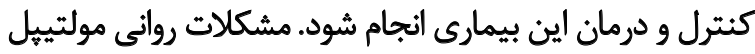

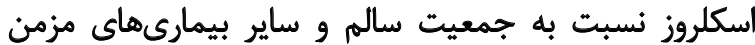

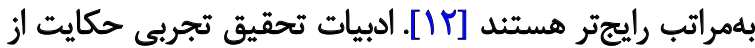

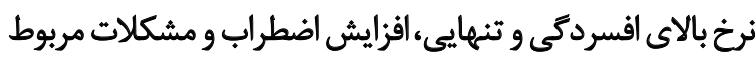

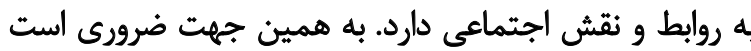
كه راهكارهاى مناسب و مؤثرى براى بهتر زيستن اين بيماران ئيدا شود. شفقت به معناى داشتن موضع مثبت نسبت به خود است،

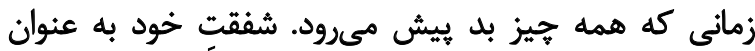

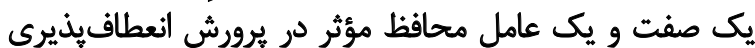

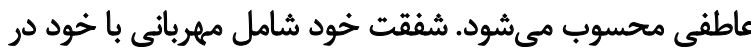

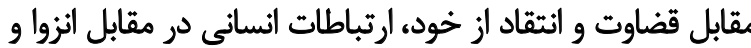

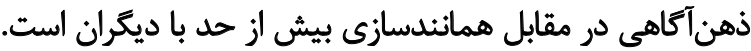

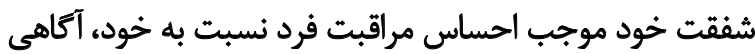

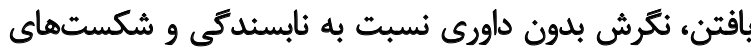

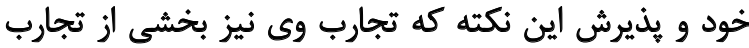

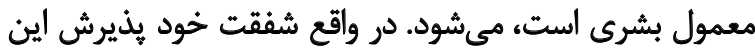

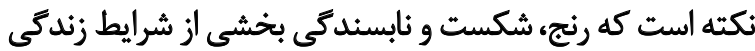

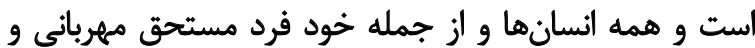

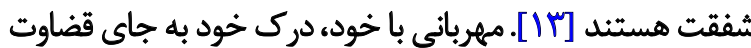

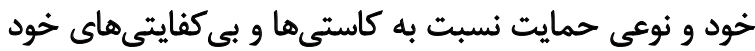

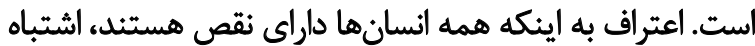

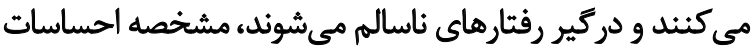

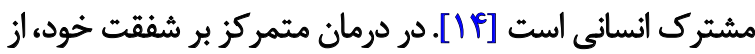

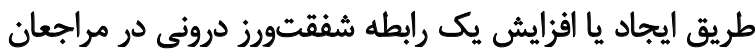

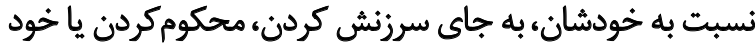

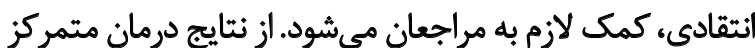

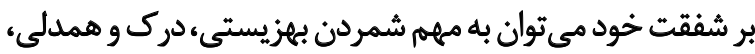

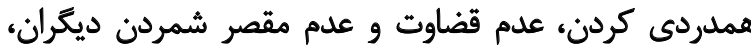

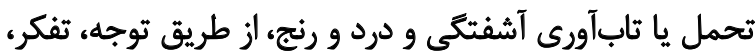

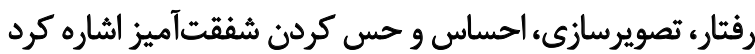

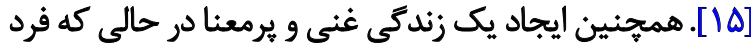


كه در ايران روايى محتوايى اين بسته با نظرخواهى از سه نفر

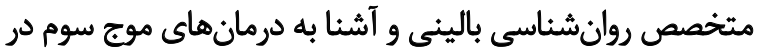

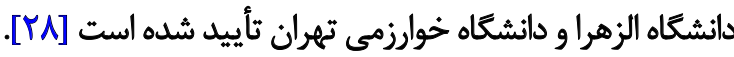

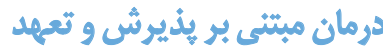

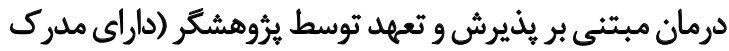

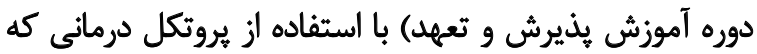

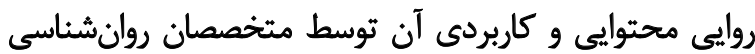

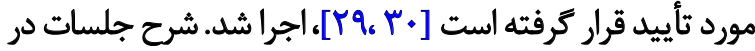
جدول شماره آمده است

متغيرهاى مورد يُؤهش در هر سه كروه، قبل و يس از انجام

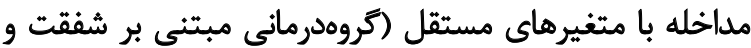
كروهدرمانى مبتنى بر يذيرش و تعهد) مورد ارزيابي قرار ترفتيندا.

ابزار مورد استفاده در يُوهش به شرح ذيل بود:

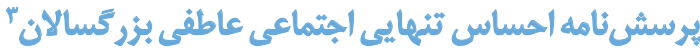

اين مقياس به وسيله ديتوماسو، برانن و بست در سال

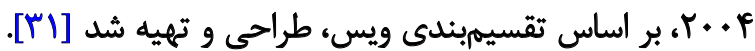

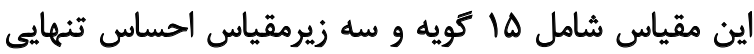

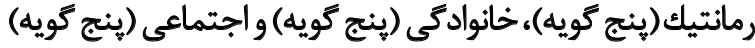

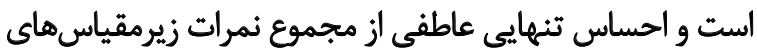

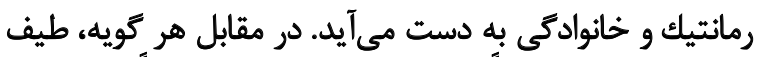

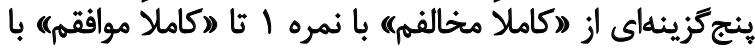

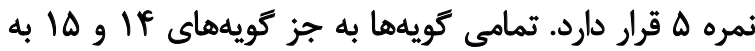

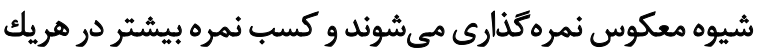

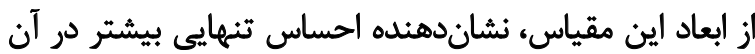

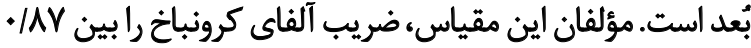

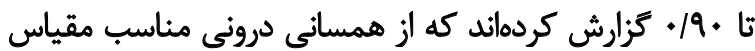

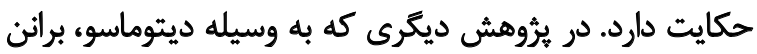

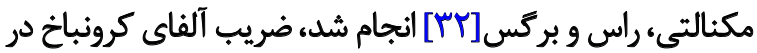

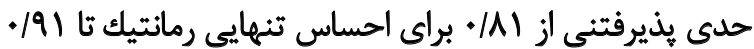

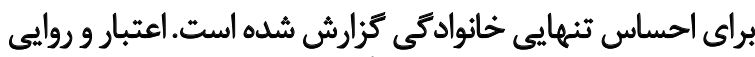

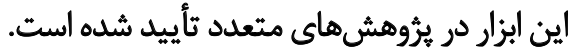

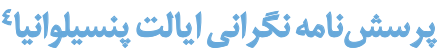

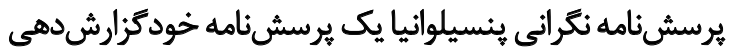

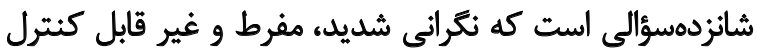

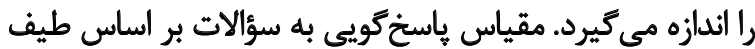

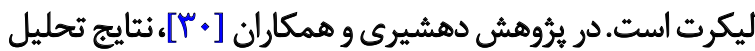

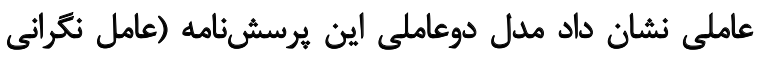

3. Social and Emotional Loneliness Scale for Adults (SELSA-S) 4. Pen State Worry Questionaire (PSWQ)
مشكلات و رنجهاى زندكى را يبيدا مى كنيه و با شفقت، توانايى

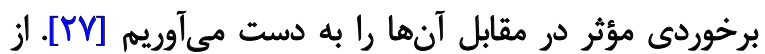

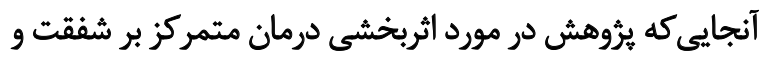

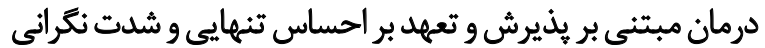

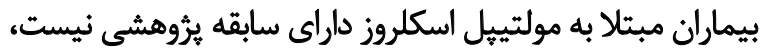

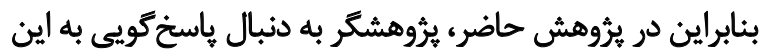

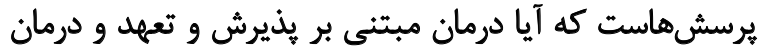

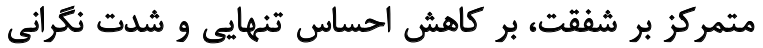

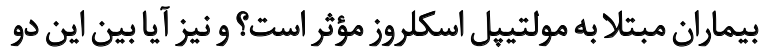

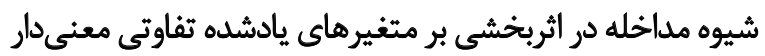

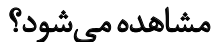
مواد و روشها

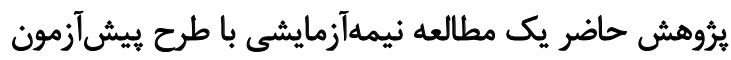

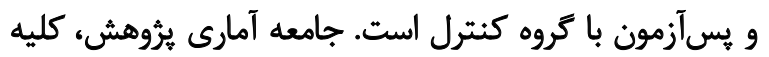

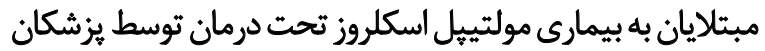

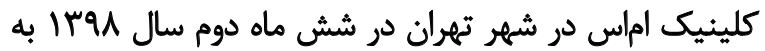

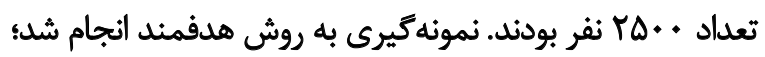

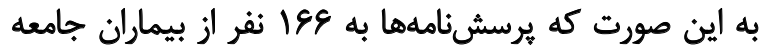

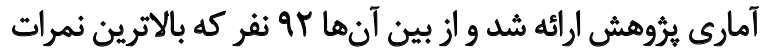

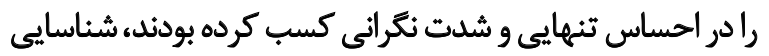

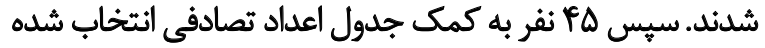

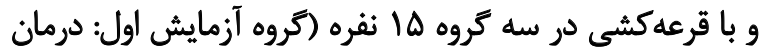

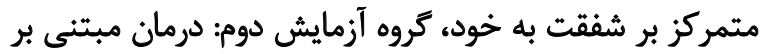

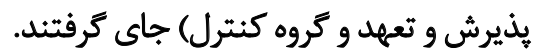
طبق منبع دكتر دلاور براى ثُوهشهايسى از نوع آزمايشى و

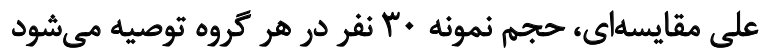

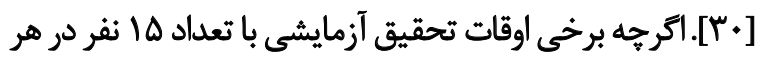

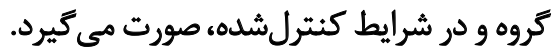
ملاكهاى ورود به مطالعه عبارت بودند از: () رضايت آكاهانه

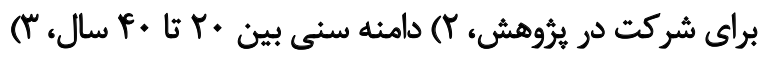

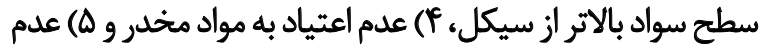

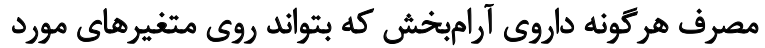

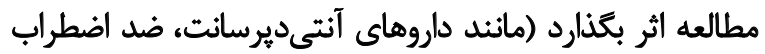

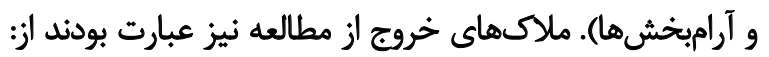

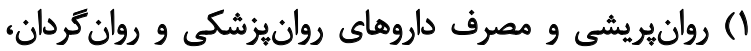

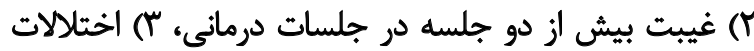

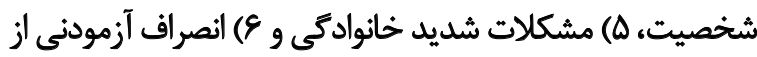

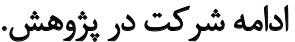
دورمان متمركز بو شقفت به خدود جلسات درمانى متمركز بر شفقت به خود، بر اساس مفاهيم

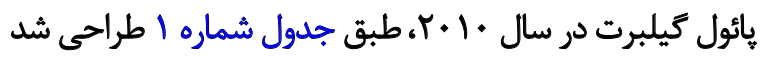


جدول ا. محتواي جلسات درمائى

دومان مثمركز بر شفقت به خود

برقرارى رابطه درمانى، آشنا نمودن افراد با موضوع يُروهش، ياسخخ به يرسش نامه و بستن قرارداد درمانى

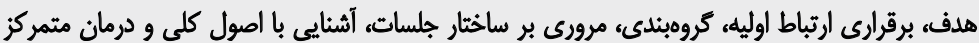

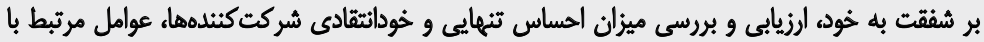

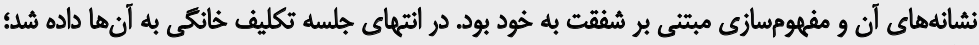

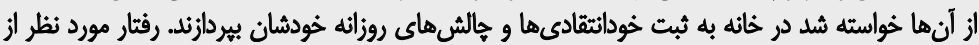

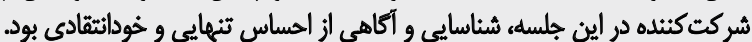

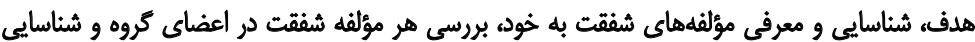

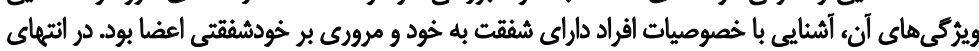

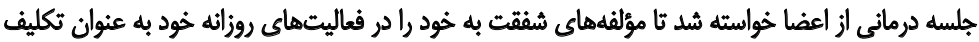

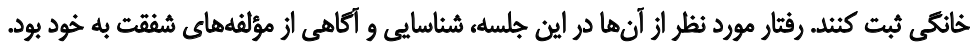

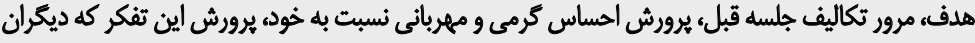

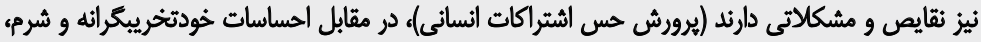

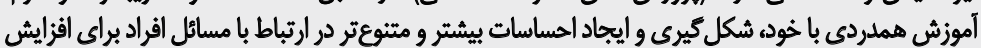

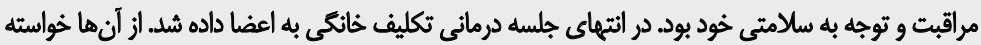

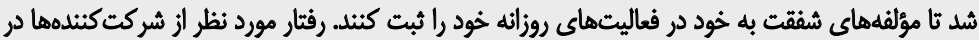

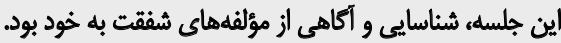

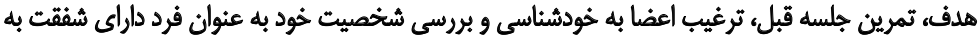

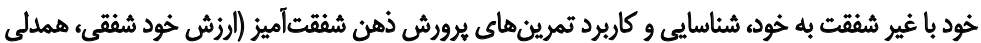

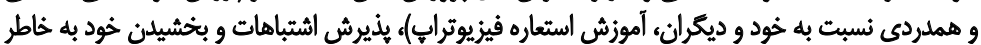

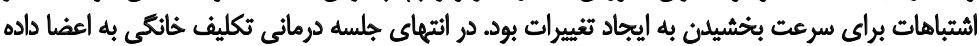

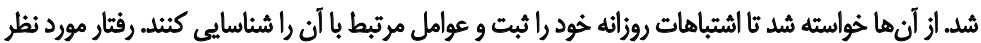

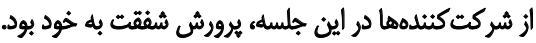

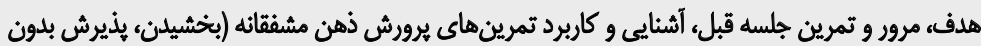

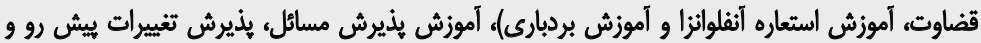

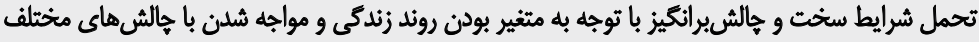

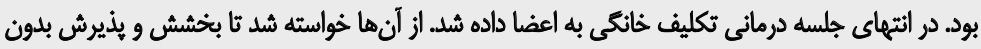

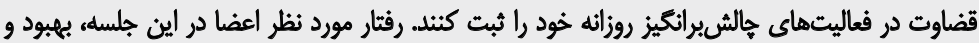

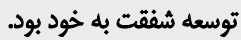

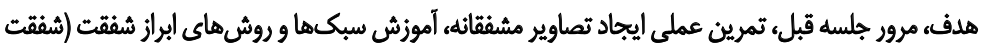

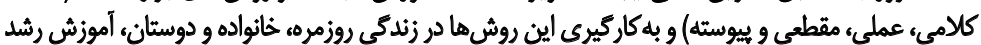

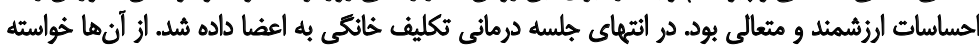

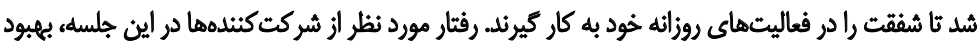

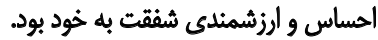

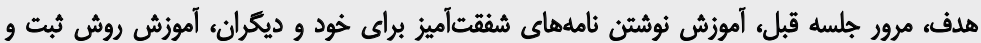

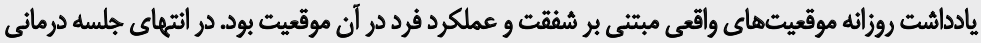

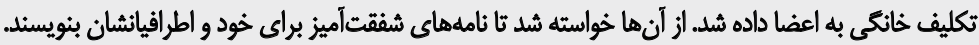

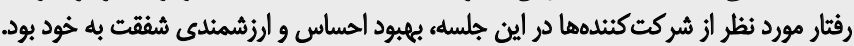

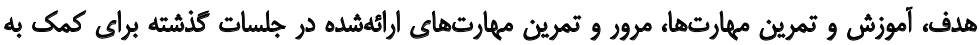

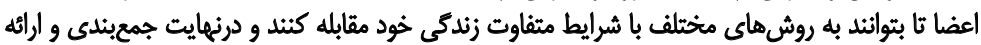

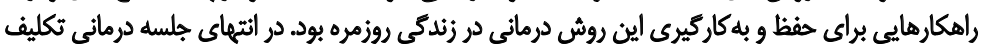

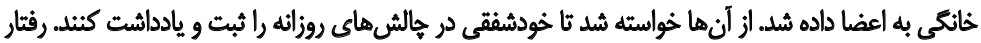

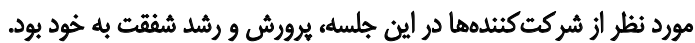

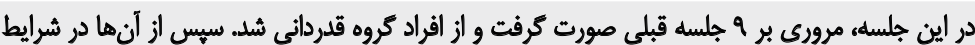

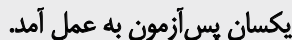

\section{جلسه امان مبتنى بر بذيرش و تعهد}

برقرارى رابطه درمانى، أشنا نمودن افراد با بار

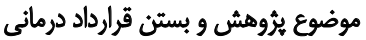

كشف و بررسى روشهاي درمانى و ارزيابيى

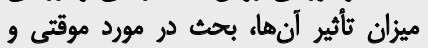

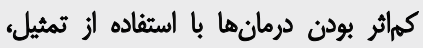
دريافت بازخورد و ارائه تكليف اليف

كمك به مراجع براى تشخيص راهبردهاى ناكارآمد و كتثرل و وبى بردن به به بيهودئى أنها، بذيرش وقايع شخُصى دردئاك بلدون كشمكش با آن ها با استفاده از تمثيل، دريافت بردي بازخورد و ارائه تكليف انيفا

توضيح در مورد اجتئاب از تجارب دردناى

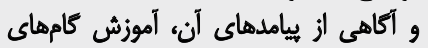

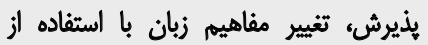
تمثيل، أموزش تن آرامي، دريافت بازخورد و

جمارم ارائه تكليف تمزيف

معرفى مدل رفتارى سلبعدى به منظور بيان

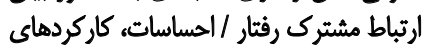

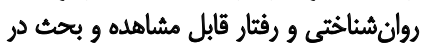
مورد ثلاش براي تغيير رفتار بر اساس آنه

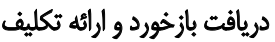

توضيح مفاهيم نقش و زمينه، مشاهده

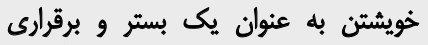
تماس با خود با استفاده از تمثيل، آكاهى بـى

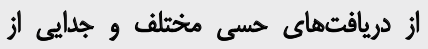

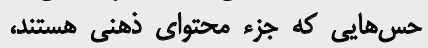
دريافت بازخورد و ارائه تكليف مخلي تفن

توضيح مغهوم ارزشها، ايجاد انكيزه براى

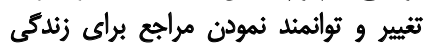
بهتر، تمرين تمركز، دريافت بازخورد و الرائه تكليف

آموزش تعهل به عمل، شناسايي طرحهاى

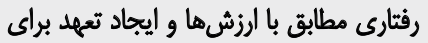

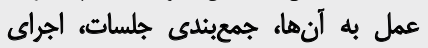
يسآزمون
دوم

سوק

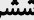

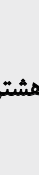


جدول r. نتايج تحليل كواريانس تكمتغيره براي مقايسه تأثير درمان متمركز بر شفقت به خود با درمان مبتنى بر يذيرش و تعهد بر ميزان احساس تنهايى مبتلايان به مولتييلاسكلروز

\begin{tabular}{|c|c|c|c|c|c|c|}
\hline ضريب اتا & سطح معنى دارى & $\mathbf{F}$ & ميانكين مجذورات & دوجه آزادى & مجموع مجذورات & منبع تغييرات \\
\hline H/TY & .1 .01 & $\Delta / q^{*}$ & $\mathrm{rVA} / \mathrm{Fq}$ & 1 & $\mathrm{TVA} / \mathrm{Fq}$ & كروه \\
\hline- & - & - & $g$ TISP & rA & $|F T / g|$ & خطا \\
\hline- & - & - & - & r. & $19 \Delta / 4 \Delta$ & كل \\
\hline
\end{tabular}

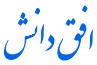

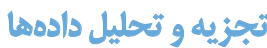

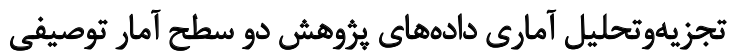

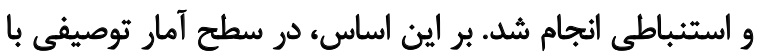

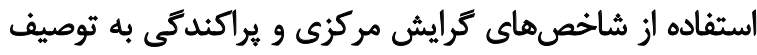

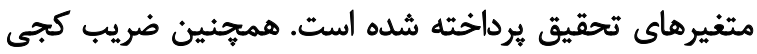

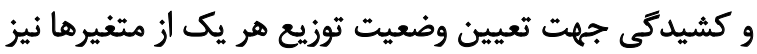

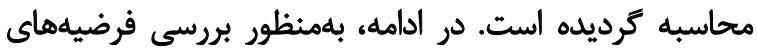

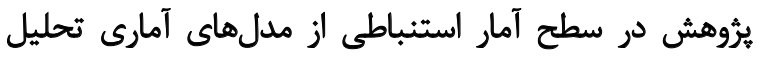

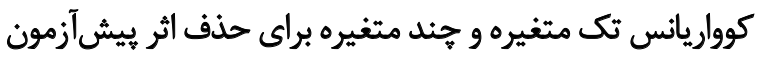
استفاده شله است.

ييش از انجام تحليل هاي توصيفى واستنباطى نيز يرسشنامهاها

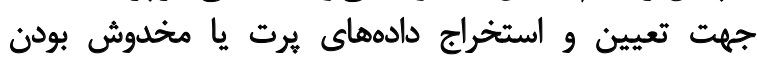

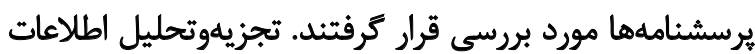

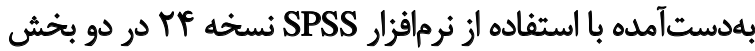

توصيفي و استنباطي انجام بذيرفت.

يافتئها

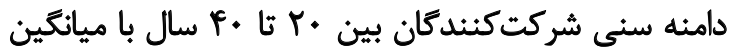
بNAF

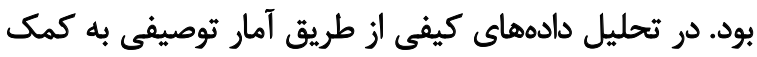

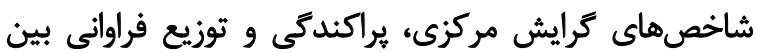

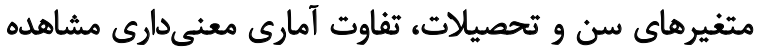

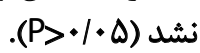

عمومى و فقدان نكرانى) نسبت به مدل تكعاملى داراى برازش

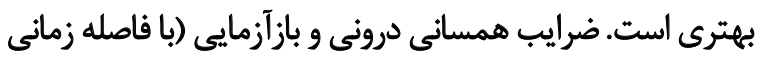

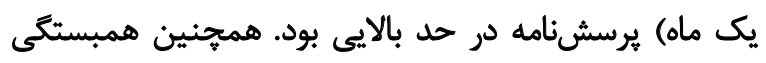

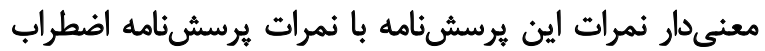

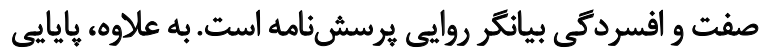

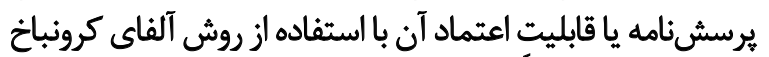

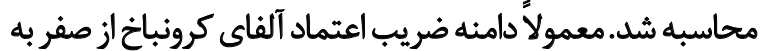

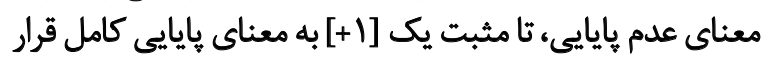

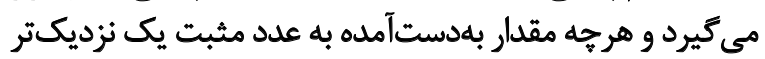

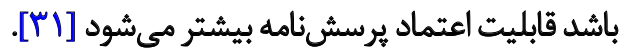

مالامثاث اخلاقى

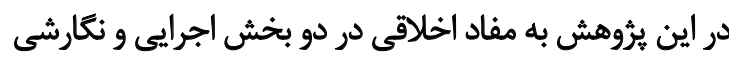

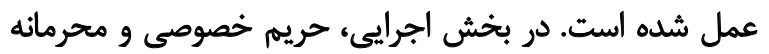

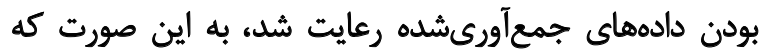

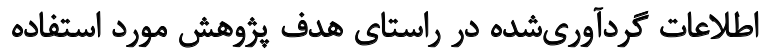

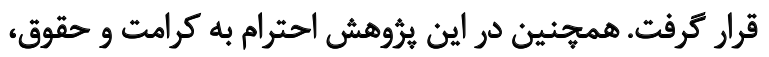

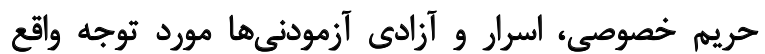

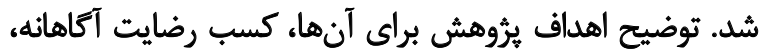

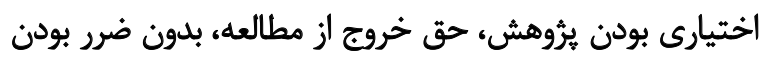

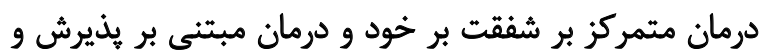

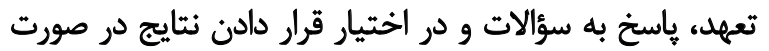

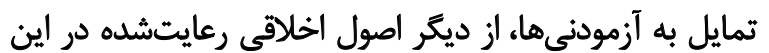

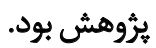

در آزمون بررسى نرمال بودن توزيع دادهها در كليه متغيرهاى

جدول r. نتايج تحليل كواريانس تكمتغيره براى مقايسه تأثير درمان متمركز بر شفقت به خود با درمان مبتنى بر بذيرش و تعهد بر ميزان نكرانى مبتلايان به مولتييل اسكلروز

\begin{tabular}{|c|c|c|c|c|c|c|}
\hline ضريب اتا & سطح معنى دارى & $\mathbf{F}$ & ميانكين مجذورات & درجه آزادى & مجموع مجذورات & منبع تغييرات \\
\hline .191 & $.1 . .1$ & $P r / 8$. & $\Delta r+/ A r$ & 1 & $\Delta r \cdot / A r$ & كروه \\
\hline - & - & - & NGT & M & rFV/AT & خطا \\
\hline - & - & - & - & $r$. & $q \cdot W / \cdot$. & كل \\
\hline
\end{tabular}

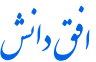


روانشناختى كاهش يافته و درنتيجه ادراك فرد از توانايىهاى

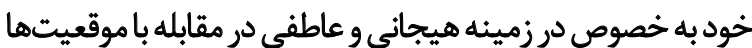
و شرايط تنشزا بهبود مي ديابد.

نتيجليَّيرى

يافتهاى مطالعه حاضر بيانكر اثربخشى هر دو درمان متمركز

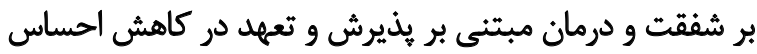

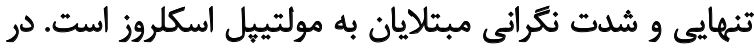

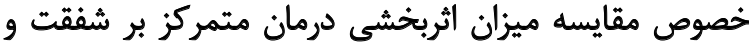

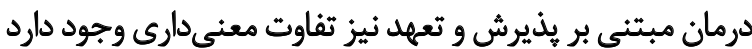

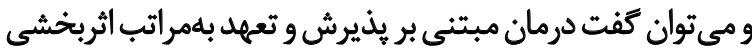

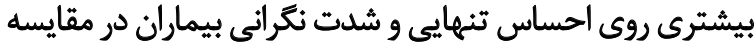

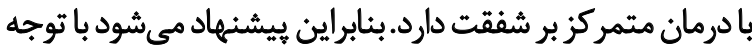

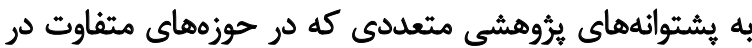

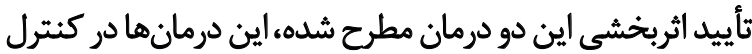

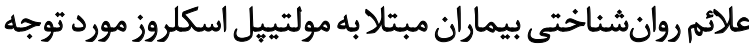

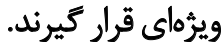

\section{محدوديتها و ييشنئادهاي يُورهشى}

از محدوديتهاي اين يُؤوهش مي توان به ناتوانى در كنترل

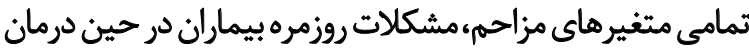

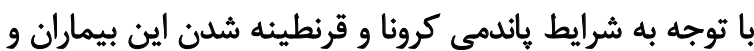

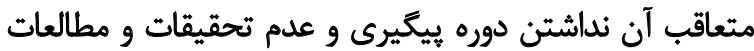

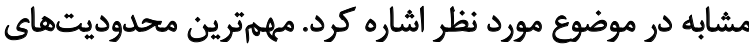

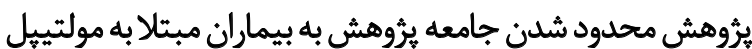

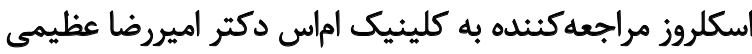

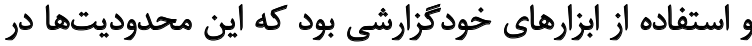

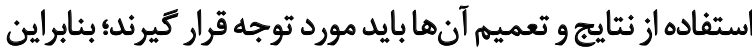

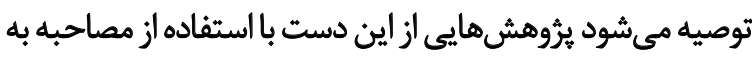
جاي يرسشنامه صورت يذيرد.

با توجه به نتايج حاصل از اين يُروهش يبشنهاد مي ئشود در

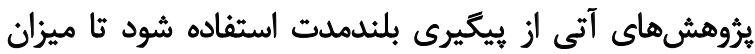

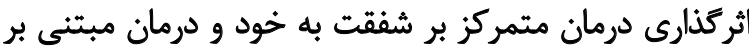

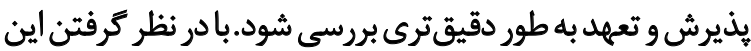

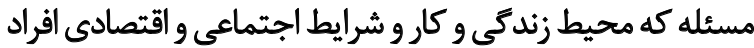

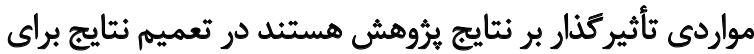

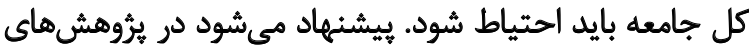

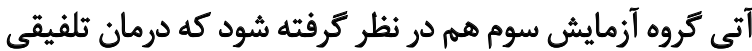

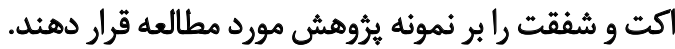

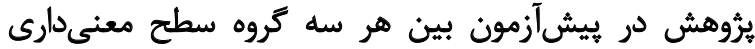

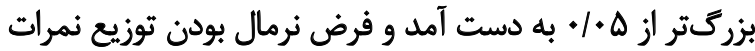

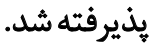

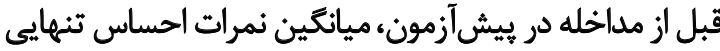

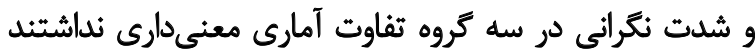

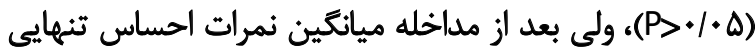

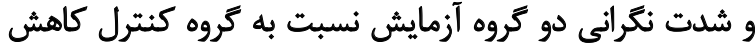

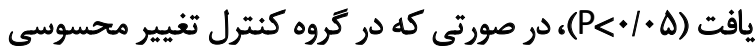

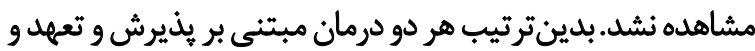

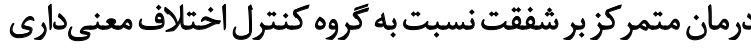

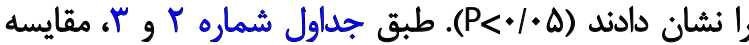

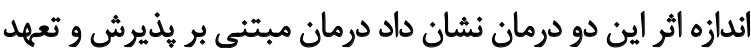

در مقايسه با درمان متمركز بر شفقت، اثربخشى بان بالاترى دارد.

بحث

اين يُروهش با هدف مقايسه اثربخشى درمان مبتنى بر بذيرش

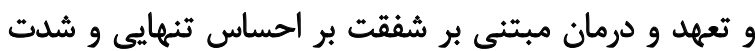

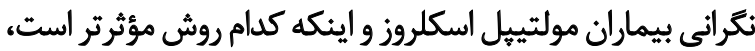

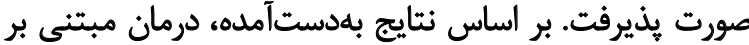

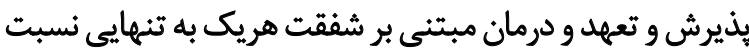

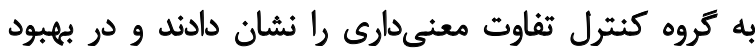

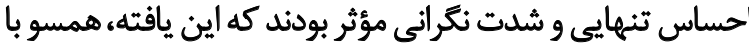

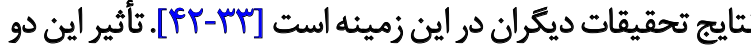

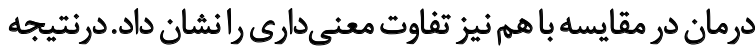

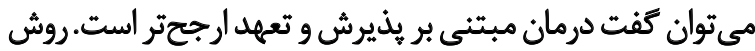

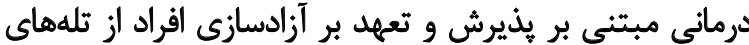

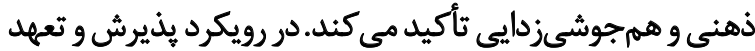

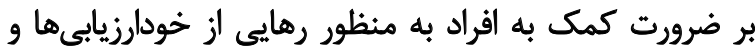

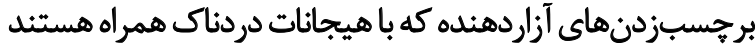

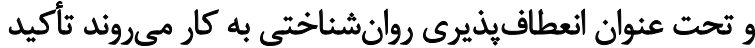

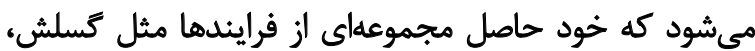

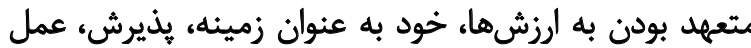

$$
\text { متعهدانه و ذهن أكاهى است. }
$$

درمان متمركز بر شفقت به دنبال شفافسازى اجزاي اصلى توإي

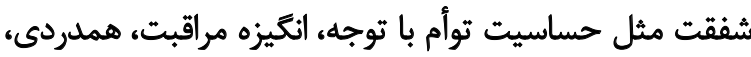

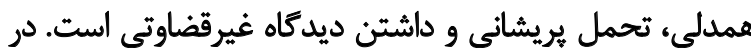

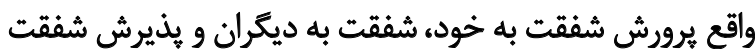

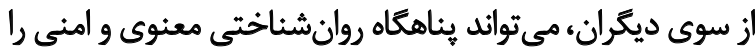

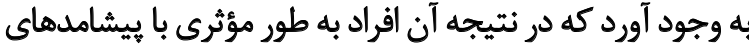

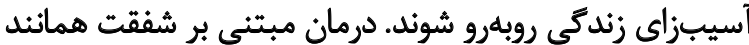

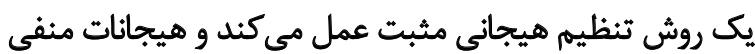

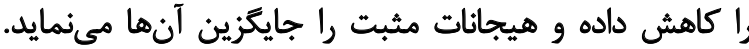
به نظر مىرسد به واسطه اين خودتنظيمى هيجانى، مشكلات 
ماحظات اخلاقى

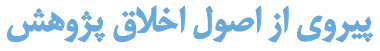

اين مطالعه با كد اخلاق IR.IAU.TJ.REC.1399.012 به إنهات تصويب دانشكاه آزاد اسلامي واحد تربتجام رسيده است.

$$
\text { ماهي هالم }
$$

اين مقاله حاصل رساله دانشجويى مقطع دكتراى خانم

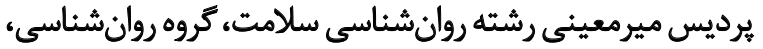

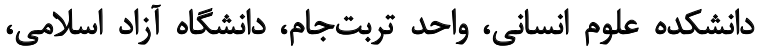
تربتجام، ايران است.

$$
\text { مشاركت نويسندكًان }
$$

ايده اصلى اجراى يروتكل، اجراو تدوين نسخه خطى: يرديس ئيس

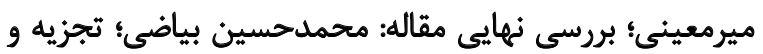

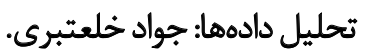

$$
\text { تقارض منأع }
$$

هيجگ گونه تعارض منافعى بين نويسندكان وجود ندارد.

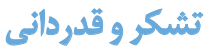

از همكارى آقاى دكتر اميررضا عظيمى صائين در تمام مراحل اجرايى و علمى يروهش حاصر صميمانه تشكر مي نماييم. 


\section{References}

[1] Hauser SL, Cree BAC. Treatment of multiple sclerosis: A review. The American Journal of Medicine. 2020; 133(12):1380-90.e2. [DOI:10.1016/j.amjmed.2020.05.049] [PMID] [PMCID]

[2] Dehghan A, Memarian R. [Abundance of stress, anxiety and depression in multiple sclerosis patients (Persian)]. Alborz University Medical Journal. 2013; 2(2):82-8. [DOI:10.18869/acadpub.aums.2.2.82]

[3] Tosifian N, Ghaderi Bagejan K, Mahmoodi A, Khaledian M. [Structural modeling of early maladaptive schemas and executive functions of people diagnosed with MS emphasizing on the role of the sense of loneliness factor (Persian)]. Journal of Neuropsychology. 2017; 3(10):93-108. http://clpsy.journals.pnu.ac.ir/article_4372. html?lang=en

[4] Ebrahimi A, Eftekhari E, Etemadifar M. [Effects of whole body vibration on hormonal \& functional indices in patients with multiple sclerosis (Persian)]. The Indian Journal of Medical Research. 2015; 142(4):450-8. [DOI:10.4103/0971-5916.169210] [PMID] [PMCID]

[5] Khezri-Moghaddam N, Ghorbani N, Bahrami-Ehsan H, Rostami R. [Efficacy of group therapy on reduction of psychological signs of multiple sclerosis patients (Persian)]. Journal of Clinical Psychology. 2012; 4(1):13-22. [DOI:10.22075/jcp.2017.2075]

[6] Damanni E, Rahimian S, Karimzaee T, Maleki S. Health-related quality of life assessment in people with MS city of Iranshahr using the Second Version of the Questionnaire Sf-36. American Academic Scientific Research Journal for Engineering, Technology, and Sciences. 2017; 32(1):235-42. https://asrjetsjournal.org/index.php/American_Scientific_Journal/article/view/3040

[7] Mohr DC, Pelletier D. A temporal framework for understanding the effects of stressful life events on inflammation in patients with multiple sclerosis. Brain, Behavior, and Immunity. 2006; 20(1):27-36. [DOI:10.1016/j.bbi.2005.03.011]

[8] Brambilla R. The contribution of astrocytes to the neuroinflammatory response in multiple sclerosis and experimental autoimmune encephalomyelitis. Acta Neuropathologica. 2019; 137(5):757-83. [DOI:10.1007/s00401-019-01980-7] [PMID] [PMCID]

[9] Leavitt VM, Riley CS, De Jager PL, Bloom S. Esupport: Feasibility trial of telehealth support group participation to reduce loneliness in multiple sclerosis. Multiple Sclerosis Journal. 2020; 26(13):17971800. [DOI:10.1177/1352458519884241] [PMID]

[10] Sharifi M, Mohammad-Aminzadeh D, Soleimani sefat E, Sudmand $\mathrm{N}$, Younesi J. [Relationship of deterministic thinking with loneliness and depression in the elderly (Persian)]. Iranian Journal of Ageing. 2017; 12(3):276-87. http://salmandj.uswr.ac.ir/article-1-1076-en. html [DOI:10.21859/sija.12.3.276]

[11] Abdollahpour I, Nedjat S, Mansournia MA, Eckert S, WeinstockGuttman B. Stress-full life events and multiple sclerosis: A population-based incident case-control study. Multiple Sclerosis and Related Disorders. 2018; 26:168-72. https://www.sciencedirect.com/ science/article/abs/pii/S2211034818303389

[12] Spencer LA, Silverman AM, Cook JE. Adapting to multiple sclerosis stigma across the life span. International Journal of MS Care. 2019; 21(5):227-34. [DOI:10.7224/1537-2073.2019-056] [PMID] [PMCID]

[13] Raque-Bogdan TL, Piontkowski S, Hui K, Ziemer KS, Garriott PO. Self-compassion as a mediator between attachment anxiety and body appreciation: An exploratory model. Body Image. 2016; 19:2836. [DOI:10.1016/j.bodyim.2016.08.001] [PMID]
[14] Neff KD, Rude SS, Kirkpatrick KL. An examination of self-compassion in relation to positive psychological functioning and personality traits. Journal of Research in Personality. 2007; 41(4):908-16. [DOI:10.1016/j.jrp.2006.08.002]

[15] Ahmadpour Dizaji J, Zahrakar K, Kiamanesh A. [Comparative efficacy of compassion focused therapy (CFT) and well being therapy (WT) on psychological capital in female college students with romantic failure (Persian)]. Scientific Research Quarterly of Woman and Culture. 2017; 9(31):7-21. http://jwc.iauahvaz.ac.ir/ article_532089_en.htm

[16] Harris R. Embracing your demons: An overview of acceptance and commitment therapy. Psychotherapy in Australia. 2006; 12(4):2-8. http://psychsurfer.com/for_clinicians/ACT_files/Harris\%20-\%20 Embracing\%20Demons.pdf

[17] Flaxman PE, Blackledge JT, Bond FW. Acceptance and commitment therapy: Distinctive Features. Amsterdam: Routledge 2010. https://www.routledge.com/Acceptance-and-Commitment-Therapy-Distinctive-Features/Flaxman-Blackledge-Bond/p/ book/9780415450669

[18] Kashdan TB, Ciarrochi JV, editors. Mindfulness, acceptance, and positive psychology: The seven foundations of well-being. Oakland California: New Harbinger Publications; 2013. https://www.newharbinger.com/9781608823376/

[19] Parsa M, Sabahi P, Mohammadifar MA. [The effectiveness of acceptance and commitment group therapy to improving the quality of life in patients with multiple sclerosis (Persian)]. Journal of Clinical Psychology. 2018; 10(1):21-8. [DOI:10.22075/jcp.2018.11686.1156]

[20] Jahangiri MM. [The effectiveness of acceptance and commitment therapy on reducing intensity pain in patients with multiple sclerosis (Persian)]. Research in Clinical Psychology and Counseling. 2018 8(2):116-27. [DOI:10.22067/ijap.v8i2.67091]

[21] Sheydayi Aghdam S, Shamseddini lory S, Abassi S, Yosefi S, Abdollahi S, Moradijoo M. [The effectiveness of treatment based on acceptance and commitment in reducing distress and inefficient attitudes in patients with MS (Persian)]. Thoughts and Behavior in Clinical Psychology. 2015; 9(34):57-66. https://jtbcp.riau.ac.ir/article_108_en.html?lang=fa

[22] Rajabi S, Yazdkhasti F. [The effectiveness of acceptance and commitment group therapy on anxiety and depression in women with MS who were referred to the MS association (Persian)]. Journal of Clinical Psychology. 2014; 6(1):29-38. [DOI:10.22075/jcp.2017.2152]

[23] Farahani $M$, heydari H. [The effectiveness of acceptance and commitment therapy on resiliency of MS patients (Persian)]. Rooyesh. 2018; 7(6):149-62. http://frooyesh.ir/article-1-580-en.html

[24] Shameli L, Davodi M, Mottaghi Dastenaee S. [The effectiveness of acceptance and commitment therapy on logical memory and problem solving skill in people with multiple sclerosis (Persian)]. Journal of Cognitive Psychoogy. 2019; 7(2):51-62. http://jcp.khu.ac.ir/ article-1-3143-en.htm

[25] Ghadampour E, Marmazipour Z, Ranjbordar M, Aj A, Pireinoldin S yousefvand $M$. [The effectiveness of acceptance and commitmentbased therapy on $g$ reduce cognitive conflicts and negative selfcoming thoughts (Persian)]. Iranian Journal of Nursing Research. 2019; 14(2):67-76. http://ijnr.ir/article-1-2032-en.htm

[26] Irons C, Lad S. Using compassion focused therapy to work with shame and self-criticism in complex trauma. The Australian Clinical Psychologist. 2017; 3(1):1743. https://acp.scholasticahq.com/ article/1743-using-compassion-focused-therapy-to-work-withshame-and-self-criticism-in-complex-trauma 
[27] Nuri $\mathrm{H}$, Shahabi B. [The effectiveness of self-Compassion training on increase of mothers'resiliency with autistic children (Persian)]. Knowledge \& Research in Applied Psychology. 2017; 18(3):118-26. http://jsr-p.khuisf.ac.ir/article_538049_en.html

[28] Fatolaahzadeh N, Majlesi Z, Mazaheri Z, Rostami M, Navabinejad $S$. [The effectiveness of compassion-focused therapy with internalized shame and self-criticism on emotionally abused women (Persian)]. Journal of Psychological Studies. 2017; 13(2):151-68. [DOI:10.22051/psy.2017.12381.1274]

[29] Hazavei F, Robatmeili S. [The effect of "acceptance and commitment therapy" on psychological flexibility and behavioral inhibition of adolescents with social anxiety disorder (Persian)]. Journal of Health Promotion Management. 2019; 8(6):18-29. http://jhpm.ir/ article-1-1016-en.html

[30] Dehshiri G, Golzari M, Borjali A, Sohrabi F. [Psychometrics particularity of farsi version of pennsylvania state worry questionnaire for college students (Persian)]. Journal of Clinical Psychology. 2009; 1(4):67-75. [DOI:10.22075/jcp.2017.1988] https://jcp.semnan. ac.ir/article_1988_54837f3a911a6b8d08828ca73114c81c.pdf

[31] DiTommaso E, Turbide J, Poulin C, Robinson B. L'Echelle de solitude Sociale et Emotionnelle (ESSE): A French-Canadian adaptation of the social and emotional loneliness scale for adults. Social Behavior and Personality: An International Journal. 2007; 35(3):339-50. [DOI:10.2224/sbp.2007.35.3.339]

[32] DiTommaso E, Brannen-McNulty C, Ross L, Burgess M. Attachment styles, social skills and loneliness in young adults. Personality and Individual Differences. 2003; 35(2):303-12. https://www.sciencedirect.com/science/article/abs/pii/S0191886902001903

[33] Iverach L, Menzies RG, Menzies RE. Death anxiety and its role in psychopathology: Reviewing the status of a transdiagnostic construct. Clinical Psychology Review. 2014; 34(7):580-93. [DOI:10.1016/j.cpr.2014.09.002] [PMID]

[34] Najjari F, Khodabakhshi Koolaee A, Falsafinejad MR. [The effectiveness of group therapy based on Acceptance and Commitment (ACT) on loneliness and psychological adjustment in women after divorce (Persian)]. Journal of Torbat Heydariyeh University of Medical Sciences. 2017; 5(3):68-75. http://jms.thums.ac.ir/article-1-459-en. html

[35] Mousavi S, Ahadi H, Khalatbari J, Mansheie Gh, Koohmanai SH. [Effectiveness of acceptance and commitment group therapy on psychological stress, loneliness and blood glucose In patients with diabetes (Persian)]. Journal of Guilan University of Medical Sciences. 2018; 26(104):72-9. http://journal.gums.ac.ir/article-1-1576-en. html

[36] Javanbakht Z, Manshey G. [The effectiveness of acceptance and commitment based treatment on meaning of life and feeling lonely of adolescents in the alternative care center (Persian)]. Quarterly Journal of Social Work. 2017; 5(4):32-9. http://socialworkmag.ir/ article-1-165-en.html

[37] Ratajska A, Zurawski J, Healy B, Glanz BI. Computerized cognitive behavioral therapy for treatment of depression in multiple sclerosis: A narrative review of current findings and future directions. International Journal of MS Care. 2019; 21(3):113-23. [DOI:10.7224/15372073.2017-094] [PMID] [PMCID]

[38] Akbari Klor S, Habibi M, Ghator Z, Azimi Raviz F. [The effectiveness of group -based compassion therapeutic on uncertainty and concern in female students with generalized anxiety disorder (Persian)]. Scientific Research Quarterly of Woman and Culture. 2019; 11(40): 53-66. http://jwc.iauahvaz.ac.ir/article_667225.html?lang=en
[39] Ahmadi R, Sajjadian I, Jaffari F. [The effectiveness of compassionfocused therapy on anxiety, depression and suicidal thoughts in women with vitiligo (Persian)]. Journal of Dermatology and Cosmetic. 2019; 10(1):18-29. http://jdc.tums.ac.ir/article-1-5369-en.html

[40] Alighanavati S, Bahrami F, Godarzi K, Rouzbahani M. [Effectiveness of compassion-based therapy on rumination and concern of women with breast cancer (Persian)]. Quarterly Journal of Health Psychology. 2018; 7(27):152-68. [DOI:10.30473/hpj.2018.38658.3886] http://hpj.journals. pnu.ac.ir/article_5249.html?lang=en 